\title{
Work-Related Perks Stimulation and Corporate R\&D Investment in Chinese Listed Companies of Emerging Market
}

\author{
Tao Jiang \\ Nanjing University of Finance and Economics \\ Xinxin Liao \\ Guangzhou Finance Holding Group Co. LTD. \\ Jun Liu \\ Guangdong University of Finance and Economics
}

Based on the high risk and uncertainty of innovative behaviors, this paper studies the role and effect of work-related perks in the contract that encourages executives to respond to innovation in Chinese listed companies. From the manager risk-taking perspective, empirical testing with all A-share listed companies in P. R. China from 2007 to 2012 in fast-growing market found that under the control of monetary compensation and equity incentives, work-related perks promote an incentive and synergistic effect on corporate innovation; but the above effects are mainly observed in emerging high-tech companies that are strongly relied on corporate innovations. Therefore, the above results are not affected by differences in corporate governance, and may eliminate the opportunism behaviors of executives while managing the enterprise's innovative activities. The presented model could possibly be found useful to formulate and motivate executives to invest in innovation and minimize the embezzlement in fast-growing companies in emerging market.

Keywords: work-related perks, tolerance for failure, R\&D investment, incentive effect, risk-taking

\section{INTRODUCTION}

Innovation strategy is an important strategic content of developing countries in the emerging market, and it is also a key factor driving the sustainable development of many emerging economies and the longterm performance growth of enterprises. However, innovation activities often face high uncertainty and high risk, and have a long span, with higher performance fluctuations and the possibility of failure. Riskadverse executives often underinvest in R\&D (Bhattacharya et al. 2017). Therefore, a contract that can motivate executives to increase investment in innovation is very important for companies (Kiazad, Kraimer, and Seibert 2019, Rassenfosse, Jaffe, and Raiteri 2019).

Existing studies have found that performance-based short-term rewards are not conducive to corporate innovation, while long-term incentives such as stock options can promote corporate R\&D investment (Shen 2012). However, the existing studies only consider the explicit profit and loss of stock options in isolation 
without including stock options into executives' compensation to consider the comprehensive profit and loss of the overall incentive contract portfolio and ignore the impact of hidden costs on the risk-taking and innovative behaviors of executives (Low 2009). Considering the hidden costs, risk-averse executives may avoid high-risk innovation investments and choose low-risk projects. Amabile (1996) and other studies have found that in addition to focusing on long-term performance, it is more important for innovative compensation contracts to be able to tolerate repeated attempts and mistakes by innovators without definite directions. For example, Manso (2011) and Edere and Manso (2014) adopted theoretical derivation and experimental research respectively to prove that the combination of tolerance of early failure of executives and reward for long-term success can effectively stimulate innovation. This contradicts to the current explicit compensation contracts which are simply rewarded based on the ex-post performance, and cannot tolerate early failures in managers' innovation practices. This article finds that work-related perks are less relied on corporate performance and may have positive influences on corporate innovation to a certain degree. The study in this article build a model to explores the incentive effects of work-related perks that are more tolerable to short-term failures in corporate $R \& D$ investment in different industries, and under different company governances while controlling currency compensation and equity incentives. This article contributes to deeper understanding that under the conditions of strong government regulation in emerging market, listed companies have developed a novel incentive mechanism which encourages managers to invest in R\&D through work-related perks as a flexible way to enhance company value which is different from the usual work-related perks mechanism in developed economies.

The remainder of the paper is organized as follows. Section 2 describes the institutional features of the managerial labor market in Chinese SOEs and develops our hypotheses. Section 3 presents the data and discusses our sample and methodology. Section 4 presents the main empirical results. Section 5 reports results for a number of robustness tests. Section 6 concludes with a brief summary and discussion.

\section{RELATED WORK AND HYPOTHESE DEVELOPMENT}

The innovation activities of enterprises often contain high uncertainty and high risk (Chang et al. 2015). Compared with other business activities, they have higher performance volatility and failure. In addition, innovation activities usually span a long period of time (usually ten years or more), so the results are highly unpredictable, which is also one of its high-risk components.

The employment security and income of agents (executives) are tied to a certain company, so agents are often risk-adverse. If they encounter innovation failures, these agents may also face suspension of their tenure and negative reputation in the labor market, because shareholders cannot judge whether these failures are caused by environmental factors such as market downturns or due to poor agent ability (Wiseman and Gomez-Mejia 1998). To sum up, these factors together lead to the risk aversion of agents

The risk aversion attribute and behavior of the agent will have a negative impact on various business activities of the company, and ultimately affect the value of the company. For example, Low (2009) found that companies that lack incentives for CEO risk-taking behavior will face higher corporate risk and the decline of corporate value; and incentives for executives' risk-taking behavior can help companies achieve good performance in investment decisions, capital structure decisions, and corporate mergers and acquisitions (Tchistyi, Yermack, and Yun 2011), and help improve the efficiency of capital allocation (Adam, Fernando, and Golubeva 2015) and corporate value (Thornton Jr., Knopf, and Nam 2002). Especially in the innovation activities of enterprises, risk-taking is a key factor affecting enterprise innovation decision-making. A higher level of risk-taking is conducive to enhancing the enterprise's innovation enthusiasm and innovation investment, and has a significant impact on enterprise performance and long-term development (Atuahene-Gima, Slater, and Olson 2005, Chen, Lin, and Chang 2009). Therefore, designing a compensation contract that can motivate executives to take risks in an enterprise's innovation activities is very important to promote the enterprise's innovation activities.

There has been a lot of research on motivating managers to take risks. Carpenter (2000) believes that stock options based on long-term performance have convex characteristics, allowing managers to share the long-term benefits brought by innovation to the enterprise, and at the same time, they can evade exercise 
by giving up exercise in the event of innovation failure. The potential losses caused by the decline in stock prices are not punitive for managers, which can increase the managerial preference for risk, help overcome the manager's risk aversion, and encourage the manager's risk-taking behaviors. Option incentives can improve the efficiency of R\&D and increase the patent productivity of enterprises (Chang et al. 2015).

This article believes that although in the case of project failure, executives can circumvent the potential losses caused by the decline in stock prices by waiving their rights, but the short-term profit decline of the company caused by innovation investment will cause direct losses to the bonus of executives. Innovation activities often require greater effort and time costs of executives and project failure will also have a negative impact on the reputation of executives in the labor market. The purely "non-punitive" feature of stock options cannot cover or compensate these explicit and implicit costs. Therefore, stock options have a limited tolerance for short-term failure, which does not necessarily increase the willingness of executives to take risks, and may even increase their risk aversion. In addition, the risk aversion hypothesis also believes that equity incentives such as executive stock ownership and stock options make executives' human capital concentrated in a certain company, reducing the degree of wealth dispersion, and increasing the degree of risk aversion of managers (Gormley and Matsa 2016, Ataay 2018).

Unlike routine operation, innovation is not simply hard work, it faces repeated trial and error. Therefore, in addition to focusing on long-term performance, it is more important for innovative compensation contracts to be able to tolerate repeated attempts and failures by innovators without a certain direction. The optimal contract that encourages innovation should be a contract that can tolerate or even encourage early failure, while also rewarding long-term success (Manso 2011).

Work-related perks (Marino and Zábojník 2008) are consumption benefits at work that are only linked to managers' rank, not to performance. Companies generally associate manager ranks with corresponding cars, secretaries, offices, and signing authority etc. to guarantees the safety of managers' food, clothing, housing and transportation. Therefore, Researchers believe that work-related perks are implicit compensations (Rajan and Wulf 2006, Jian, Li et al. 2020).

Based on the analysis in Figure 1, equity incentives, including stock options, can only provide longterm incentives for executives to carry out innovative activities, but cannot provide any guarantee for project failures. On the contrary, work-related perks cannot provide long-term incentives for managers; but it can recoup the direct loss of the executives' monetary compensation caused by the short-term profit decline caused by the innovation investment, as well as the labor, time, and reputation costs of the managers' repeated attempts and mistakes in innovative activities. It also increases managers' capacity of risk-taking in innovative investment activities, thereby achieving the purpose of tolerating early failures of innovations.

To promoting corporate innovation and enhancing executives' willingness and ability for risk-taking, companies should not only adopt stock options and other rewards for the long-term success of executives' innovative behaviors; work-related perks by providing necessary guarantees for executives in high-risk innovative activities should also be considered. Therefore, the hypothesis $\mathrm{H} 1$ of this article is proposed:

Hypothesis H1: in the case of controlling managers' salary, bonus, and equity incentives, work-related perks have incentive effects on corporate innovation investments and promote executives' risk bearing ability of short-term failures.

Based on the previous analysis, we found that stock options and work-related perks have their own strengths in promoting enterprise innovation investment and there are significant differences between these two mechanisms of encouraging managers to invest in innovation. To seek an excellent contract requires to tolerate early failure and reward long-term success, Lu (2014) found that combining the incentive schemes that tolerate early failures beforehand and the evaluation mechanism linked to performance afterwards can effectively improve the executives' innovation motivations and promote the efficiency of innovation investment.

It can be seen that the combination of the two types of incentive mechanisms, stock options and workrelated perks, can effectively compensate for the shortcomings of the other party in motivating senior 
executives to invest in innovation while exerting its own strengths, enhancing the compatibility of incentive contracts and play a synergistic effect in encouraging executives investing in corporate innovation activities. Therefore, hypothesis $\mathrm{H} 2$ is proposed:

Hypothesis H2: Work-related perks and equity incentives have a synergistic effect in promoting enterprise innovation investment.

\section{FIGURE 1 \\ LOGICAL DIAGRAM OF HYPOTHESES}

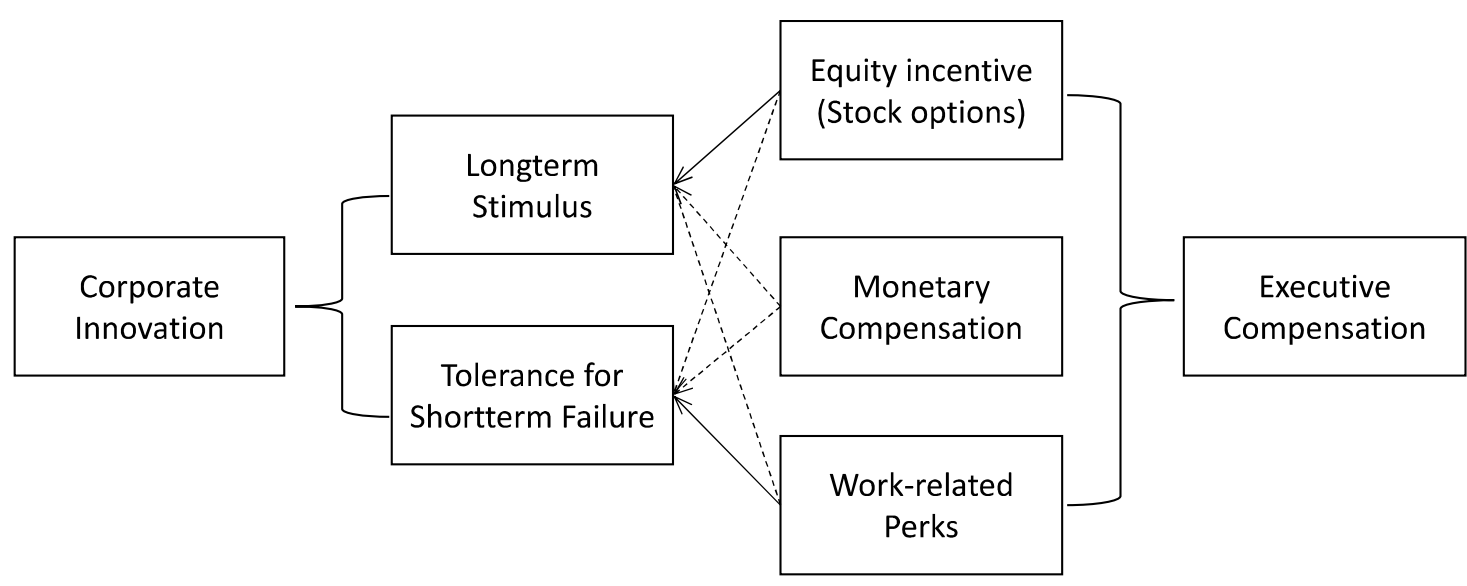

\begin{tabular}{l|c|c|c|}
\multicolumn{1}{c}{} & \multicolumn{1}{l}{$\begin{array}{l}\text { Monetary } \\
\text { Compensation }\end{array}$} & \multicolumn{1}{c}{$\begin{array}{l}\text { Equity incentive } \\
\text { (Stock options) }\end{array}$} & \multicolumn{1}{c}{$\begin{array}{l}\text { Work-related } \\
\text { Perks }\end{array}$} \\
\cline { 2 - 4 } & \multirow{2}{*}{ Success } & + & + \\
& & $(+)$ & + \\
Failure & - & - & + \\
\cline { 2 - 4 } & & $(0)$ & + \\
\hline
\end{tabular}

From an industry perspective, different industries have very different demands for R\&D investment. Compared with traditional industries, knowledge-intensive industries such as high-tech companies rely on new products and new technologies to a higher degree. According to the "demand-pull hypothesis" of R\&D investment, in order to maintain a sustainable competitive advantage, these companies have invested heavily in R\&D. Liu (2007) found that R\&D investment in high-tech industries is the main factor that promotes the growth of total factor productivity (TFP) of enterprises, which promotes the growth of enterprise productivity (Haider, Kunst, and Wirl 2020). The empirical studies of Garner and Nam (2002) found that R\&D investment directly affects the innovation speed of enterprises, which in turn affects the value of enterprises. Compared with traditional industries, the R\&D investment of high-tech enterprises also has the characteristics of higher technical content, higher knowledge barriers, and higher experience barriers. These characteristics determine that the R\&D investment of high-tech industries has a high risk and therefore requires to provide more incentives for risk-averse management to tolerate innovation failures. Therefore, compared with traditional industries, work-related perks have a stronger incentive effect in the corporate innovation of high-tech enterprises with a greater synergic effect in combine with equity incentives. Therefore, hypothesis $\mathrm{H} 3$ is proposed:

Hypothesis H3: The positive correlation between hypothesis HI and hypothesis H2 is significant in the sample of high-tech industries, but not significant in the sample of non-high-tech enterprises. 


\section{MODEL CONSTRUCTION}

\section{Variables}

Our model refers to the methods from studies of Wen and Feng (2009), Liu and Liu (2007) to calculate the $R \& D$ investment, using the development expenditure in the balance sheet and standardizing the measurement with revenue.

The measurement method of work-related perks refers to the methods of Chen, Liang, and Jiang (2010) and Chen et al. (2009). This article uses office expenses, travel expenses, business entertainment expenses, and communications in the "Other cash flow related to operating activities" table in the notes to the financial statements. The eight items of expenses, including fees, study abroad fees, board fees, trolley fees, and conference fees, are added together, and then the revenue is standardized to measure work-related perks, denoted by T_Perk1. Since the three expenses of office fee, board fee and meeting fee are extremely controversial, according to the consideration of robustness, this article also refers to the method of Lu, Wei, and $\mathrm{Li}$ (2008) to exclude office fee, board fee and meeting fee. The three expenses are removed from the method of Chen, Liang, and Jiang (2010), and only the total of the remaining five expenses is calculated, and then standardized by revenue, expressed by T Perk2. In addition, since the expenses involved in the "Other cash related to operating activities" table include operational expenses and sales expenses incurred in operating activities and sales activities, there must be some "operating" work-related perks in the normal operating activities of the enterprise, the remaining part belongs to the excessive use of management. In order to reduce the noise caused by the "operating" work-related perks in the measurement process of the proxy variable of managers' work-related perks, this paper also constructs excess work-related perks (Jian 2020 ) as an additional proxy variable of managers' work-related perks referring to the calculation methods of Luo, Zhang, and Zhu (2011) and Quan, Wu, and Wen (2010). The eight/five selected items of expenses are regressed on the variables on the right side of the model (1), and the residual $\varepsilon$ is the series of excess work-related perks, named E_Perk1 and E_Perk2 respectively.

Perk $=\beta_{0}+\beta_{1} \frac{1}{\text { Asset }}+\beta_{2} \frac{\Delta \text { Sales }}{\text { Asset }}+\beta_{3} \frac{P P E}{\text { Asset }}+\beta_{4} \frac{\text { Inv }}{\text { Asset }}+\beta_{5} \frac{\text { LnEmployee }}{\text { Asset }}+\varepsilon$

Among them, Asset is fixed assets at the end of the year, 1 Sales is the change in revenue from the main business, PPE is the net value of fixed assets, Inv is the total inventory, and LnEmployee is the logarithm of the number of employees. According to the regression model (1) by industry and year, the calculated residual $\varepsilon$ is the excess work-related perks of the enterprise management.

Finally, in order to eliminate the influence of industry factors, this paper also constructed the workrelated perks adjusted by the industry median as a proxy variable of the manager's work-related perks, named I_Perk1 and I_Perk2 respectively.

TABLE 1

\section{DEFINITIONS OF VARIABLES}

\begin{tabular}{|c|c|c|}
\hline Variables & Description & Calculation \\
\hline \multicolumn{3}{|c|}{ Panel A: Dependent Variables } \\
\hline$R \& D$ & Research and development & R\&D Investment/Revenue \\
\hline \multicolumn{3}{|c|}{ Panel B: Independent Variables } \\
\hline T_Perk1 & Total work-related perks 1 & $\begin{array}{l}\text { Summary of eight items: "travel expenses", } \\
\text { "hospitality expenses", "communication allowance", } \\
\text { "study abroad expenses", "chauffeur service cost", } \\
\text { "office expenses", "board fee" and "conference fee" } \\
\text { in the "other cash related to operating activities" in the }\end{array}$ \\
\hline
\end{tabular}


notes to the financial statements of the annual report divided by operating revenue.

T_Perk2 Total work-related perks 2 Summary of five items: "travel expenses", "hospitality expenses", "communication allowance", "study abroad expenses" and "chauffeur service cost" in the "other cash related to operating activities" in the notes to the financial statements of the annual report divided by operating revenue.

\begin{tabular}{ll}
\hline A_Perk1 & $\begin{array}{l}\text { Work-related perks 1 per } \\
\text { executive }\end{array}$ \\
\hline $\boldsymbol{A} \_$Perk2 & $\begin{array}{l}\text { Work-related perks } 2 \text { per } \\
\text { executive }\end{array}$ \\
\hline E_Perk1 & $\begin{array}{l}\text { Excessive work-related perks } \\
1\end{array}$
\end{tabular}

T_Perk1 divided by number of executives

T_Perk2 divided by number of executives

E_Perk1 is the residual of the natural logarithm regression of the reciprocal of T-Perk1 against total assets, Changes in the revenue of the standardization of total assets, net value of PP\&E, total inventory and the number of employees

E_Perk2 Excessive work-related perks 2

E_Perk2 is the residual of the natural logarithm regression of the reciprocal of T-Perk2 against total assets, Changes in the revenue of the standardization of total assets, net value of PP\&E, total inventory and the number of employees

\begin{tabular}{lll}
\hline I_Perk1 & $\begin{array}{l}\text { Industry-adjusted work-related } \\
\text { perks 1 }\end{array}$ & T_Perk1 minus the median of the industry for the year \\
\hline $\boldsymbol{I}$ Perk2 & $\begin{array}{l}\text { Industry-adjusted work-related } \\
\text { perks 2 }\end{array}$ & T_Perk2 minus the median of the industry for the year \\
\hline $\boldsymbol{P e r k} \times \boldsymbol{E X E}$ & $\begin{array}{l}\text { Interaction term of work- } \\
\text { related perk and manager }\end{array}$ & $\begin{array}{l}\text { Interaction term of work-related perk and executive } \\
\text { shareholding ratio }\end{array}$
\end{tabular}
equity incentive

\begin{tabular}{|c|c|c|}
\hline \multicolumn{3}{|c|}{ Panel C: Control Variables } \\
\hline Size & The scale of enterprise & The natural logarithm of the company's total assets \\
\hline $\mathrm{ROA}$ & Return on assets & $\begin{array}{l}\text { The total profit/total assets of the enterprise at the end } \\
\text { of the sample period }\end{array}$ \\
\hline FCF & Free cash flow & Free cash flow/total assets \\
\hline Growth & Operating revenue growth rate & $\begin{array}{l}\text { (Operating revenue of the current year - Operating } \\
\text { revenue of the previous year) / Operating revenue of } \\
\text { the previous year }\end{array}$ \\
\hline Top1 & $\begin{array}{l}\text { Proportion of the largest } \\
\text { shareholder }\end{array}$ & Proportion of the largest shareholder \\
\hline Herf & Equity concentration & $\begin{array}{l}\text { The sum of the second to tenth largest shareholder's } \\
\text { shareholding ratio and / the largest shareholder's } \\
\text { shareholding ratio }\end{array}$ \\
\hline Dual & CEO duality & $\begin{array}{l}\text { Taking the value } 1 \text { if the CEO also holds the position } \\
\text { of the chairman of the board, and } 0 \text { otherwise }\end{array}$ \\
\hline$E X E$ & Executive ownership ratio & Executive owned equity/equity \\
\hline$S O E$ & State-owned enterprise & $\begin{array}{l}\text { Taking the value } 1 \text { if it is a state-owned enterprise, and } \\
0 \text { otherwise }\end{array}$ \\
\hline Salary & Executive compensation & $\begin{array}{l}\text { The natural logarithm of the total remuneration of the } \\
\text { top three corporate executives at the end of the sample } \\
\text { period }\end{array}$ \\
\hline
\end{tabular}




\begin{tabular}{|c|c|c|}
\hline Mratio & Executives-to-staff ratio & Number of executives/number of employees \\
\hline Rpay & Executive pay-ratio & $\begin{array}{l}\text { Average salary of the top three executives/average } \\
\text { employee salary }\end{array}$ \\
\hline Compensate & $\begin{array}{l}\text { Compensation of work-related } \\
\text { perks for insufficient monetary } \\
\text { salary }\end{array}$ & $\begin{array}{l}\text { Executive excess compensation (unexpected) (Fang } \\
\text { 2012, Bebchuk, Fried, and Walker } 2002 \\
\text { Bebchuk and Grinstein 2005) }\end{array}$ \\
\hline Age & Listing years & Number of years the company went public \\
\hline$E Q$ & Enterprise information quality & Real earnings management (Li, Dong, and Lian 2011) \\
\hline Industry & Industry & $\begin{array}{l}\text { Taking the value } 1 \text { if it is corresponding industry, and } \\
0 \text { otherwise }\end{array}$ \\
\hline Year & Year & Taking the value 1 if it is current year, and 0 otherwise \\
\hline
\end{tabular}

\section{Empirical Models}

According to the research hypothesis, this paper constructs the following models: model (2) and model (3) are used to test hypothesis $\mathrm{H} 1$ and hypothesis $\mathrm{H} 2$, respectively. The definition of each variable is shown in Table 1

$$
\begin{aligned}
& R \& D=\beta_{0}+\beta_{1} \text { Perk }+ \text { Controls }+\sum \text { Industry }+\sum \text { Year }+\varepsilon \\
& R \& D=\beta_{0}+\beta_{1} \text { Perk }+\beta_{2} \text { Perk } \times E X E+\beta_{3} E X E+\text { Controls }+\sum \text { Industry }+\sum \text { Year }+\varepsilon
\end{aligned}
$$

The model (3) is based on the model (2) and adds the interaction item between the work-related perks Perk and the executive ownership ratio EXE, which is used to measure the synergy of work-related perks and manager equity incentives in motivating executives to invest in R\&D. As stock options have been rarely used in China so far (on December 31, 2005, the China Securities Regulatory Commission issued the "Administrative Measures for Equity Incentives for Listed Companies (Trial)", some companies began to implement equity incentive plans. However, the statistical results of the CSMAR database It can be seen that there were only 107 companies that issued equity incentive drafts between 2006 and 2014), and manager shareholding is more commonly used in China. Therefore, this article uses manager shareholding ratio as the proxy variable for manager equity incentives. Grouped regression is performed on model (2) and model (3) based on the classification method of high-tech enterprises ( $\mathrm{Lu}$ and Yin 2014) to test hypothesis $\mathrm{H} 3$.

\section{Control Variables}

Consistent with researches on R\&D investment of domestic and foreign companies such as Li and Song (2010), this article controls the size of the enterprise (Size), return on assets (ROA), financial leverage (Lev), and free cash flow $(F C F)$, operating revenue growth rate (Growth), shareholding ratio of the largest shareholder (Topl), degree of equity concentration (Herf), CEO duality (Dual), state-owned enterprise ( $S O E$ ), executive compensation (Salary), management-to-staff ratio (Mratio), executive-employee pay ratio (RPay), Listing years (Age), industry factor ( $\Sigma$ Industry) and year factor ( $\Sigma$ Year $)$. The definition and detailed description of these control variables are shown in Table 1.

\section{Data Source and Sample Selection}

This article selects the listed companies that traded on the Shanghai Stock Exchange and the Shenzhen Stock Exchange from 2007 to 2012 as samples, and cleans the original sample according to the following criteria: (1) Eliminate listed companies in the financial and insurance industries; (2) Eliminate listed companies that have been listed for less than one year; (3) Eliminate listed companies with incomplete data. After cleaning process, 2798 research samples were obtained, and the original data were winsorized at level $1 \%$ and $99 \%$. The data of R\&D investment comes from the development expenditure items in the balance 
sheet of the annual report; the data of managers' work-related perks comes from the following eight items: the office expenses, travel expenses, business entertainment expenses, Communication fees, study abroad fees, board fees, car fees, and conference fees in the "other cash flow related to operating activities" in the financial statement notes of the annual report. Other financial data comes from the China Stock Market \& Accounting Research (CSMAR) database.

One of the major reasons the data sampling period ends in 2012 is due to the launch of major anticorruption reforms announced by the Chinese central government on December 4, 2012 (Lin et al. 2018). The new "Eight-point Policy" directive order managers to forego conspicuous perks and other obtrusive behaviors had a significant impact on policies of work-related perks of state-owned enterprise (SOE) top executives which may have abrupt unknown impact on our model.

\section{EMPIRICAL RESULTS AND ANALYSIS}

\section{Descriptive Statistics}

The descriptive statistics of all variables are shown in Table 2. Table 3 describes the correlation coefficient matrix between the dependent variables and the independent variables. Due to space limitations, the correlation coefficient matrix between these variables and the control variable is not listed. The results in Table 3 show that the R\&D investment of the dependent variable companies and the variables that measure managers' work-related perks are significantly positively correlated at the $1 \%$ level.

TABLE 2

\section{DESCRIPTIVE STATISTICS OF ALL VARIABLES}

\begin{tabular}{llllll}
\hline Variables & Average & Median & Standard Deviation & Minimum & Maximum \\
\hline R\&D & 0.002 & 0.000 & 0.008 & 0.000 & 0.066 \\
T_Perk1 & 0.016 & 0.009 & 0.024 & 0.001 & 0.208 \\
T_Perk2 & 0.011 & 0.006 & 0.016 & 0.000 & 0.137 \\
A_Perk1 & 0.003 & 0.001 & 0.005 & 0.000 & 0.053 \\
A_Perk2 & 0.002 & 0.001 & 0.004 & 0.000 & 0.033 \\
E_Perk1 & 0.008 & 0.001 & 0.026 & -0.016 & 0.221 \\
E_Perk2 & 0.006 & 0.001 & 0.017 & -0.009 & 0.138 \\
I_Perk1 & 0.004 & -0.001 & 0.021 & -0.029 & 0.180 \\
I_Perk2 & 0.003 & -0.000 & 0.015 & -0.019 & 0.118 \\
Size & 21.762 & 21.644 & 1.146 & 18.724 & 25.721 \\
ROA & 0.038 & 0.033 & 0.058 & -0.371 & 0.208 \\
Lev & 0.198 & 0.182 & 0.156 & 0.000 & 0.724 \\
FCF & 0.041 & 0.060 & 0.147 & -0.884 & 0.374 \\
Growth & 0.207 & 0.137 & 0.520 & -0.801 & 4.590 \\
Top1 & 0.360 & 0.348 & 0.151 & 0.090 & 0.769 \\
Herf & 0.125 & 0.000 & 0.331 & 0.000 & 1.000 \\
Dual & 0.165 & 0.000 & 0.372 & 0.000 & 1.000 \\
EXE & 0.020 & 0.000 & 0.077 & 0.000 & 0.528 \\
SOE & 0.631 & 1.000 & 0.483 & 0.000 & 1.000 \\
Salary & 12.618 & 12.640 & 0.772 & 9.547 & 14.598 \\
Mratio & 0.007 & 0.003 & 0.015 & 0.000 & 0.150 \\
RPay & 6.635 & 4.964 & 5.677 & 0.171 & 33.509 \\
Compensate & -0.255 & -0.207 & 0.777 & -3.169 & 1.644 \\
Age & 9.582 & 10.000 & 4.722 & 2.000 & 22.000 \\
\hline & & & & & \\
\hline
\end{tabular}




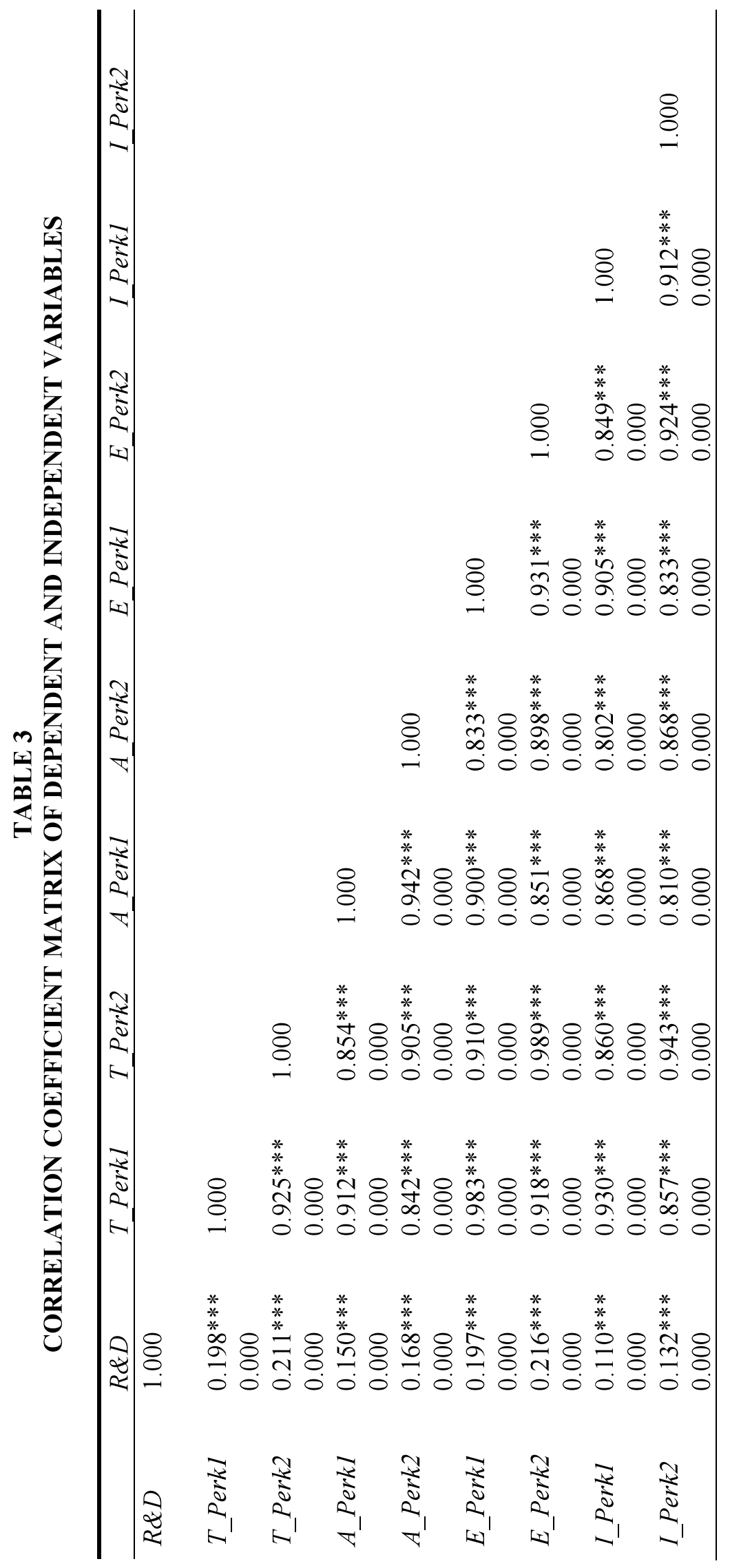

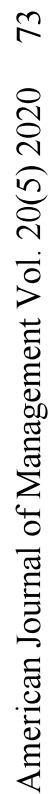




\section{Empirical Test}

Due to space limitations, some dependent variables of the empirical test only use the total work-related perks $T_{-}$Perkl consisting of eight items and the excess work-related perks E_Perkl. The five items T_Perk2,E_Perk2, and the per capita perks $A_{-}$Perk1, A_Perk2 and industry-adjusted work-related perks I_Perk1 and $I_{-}$Perk2 are presented in the robustness test section.

Table 4 shows the empirical results of managers' work-related perks and corporate R\&D investment. The results show that the coefficient of executive ownership ratio EXE in columns (1)-column (3) is not significant, indicating that equity incentives relying solely on long-term incentives does not necessarily promote managers to invest in R\&D innovation. On the contrary, when the managers' monetary salary and equity incentive $E X E$ are under control, work-related perks present significantly positively correlation with the enterprise's R\&D expenditure which verifies the hypothesis H1.

In addition, the results of columns (4) and (5) show that the work-related perks Perk and its interaction term Perk $\times E X E$ are both significantly positive, indicating that work-related perks and equity incentives have a synergistic effect on corporate innovation, verifying the hypothesis $\mathrm{H} 2$.

Table 5 is the empirical results of the grouping test of hypothesis $\mathrm{H} 1$ and hypothesis $\mathrm{H} 2$ according to high-tech enterprises and non-high-tech enterprises. The results show that, except for Perk $\times E X E$ in column (3), the coefficients of work-related perks Perk and its interaction term Perk $\times E X E$ with equity incentives are significantly positive in the high-tech enterprise sample group (column 1 to column 4). The results of sample group of non-high-tech enterprises (column 5-column 8) are not significant, which validates the hypothesis $\mathrm{H} 3$.

TABLE 4

WORK-RELATED PERKS AND CORPORATE RESEARCH AND DEVELOPMENT

\begin{tabular}{|c|c|c|c|c|c|}
\hline & & $T$ Perkl & E Perkl & $T$ Perkl & E Perkl \\
\hline & (1) & (2) & (3) & (4) & (5) \\
\hline & $R \& D$ & $R \& D$ & $R \& D$ & $R \& D$ & $R \& D$ \\
\hline \multirow[t]{2}{*}{ cons } & $0.025 * * *$ & $0.021 * *$ & $0.021 * *$ & $0.021 * *$ & $0.021 * *$ \\
\hline & $(0.004)$ & $(0.013)$ & $(0.013)$ & $(0.015)$ & $(0.017)$ \\
\hline \multirow[t]{2}{*}{$E X E$} & 0.002 & 0.001 & 0.000 & $-0.009 * *$ & $-0.009 * * *$ \\
\hline & $(0.513)$ & $(0.830)$ & $(0.854)$ & $(0.019)$ & $(0.004)$ \\
\hline \multirow[t]{2}{*}{ Perk } & & $0.032 * * *$ & $0.030 * * *$ & $0.025 * * *$ & $0.022 * * *$ \\
\hline & & $(0.000)$ & $(0.000)$ & $(0.000)$ & $(0.000)$ \\
\hline \multirow[t]{2}{*}{ Perk $\times E X E$} & & & & $0.451 * * *$ & $0.823 * * *$ \\
\hline & & & & $(0.001)$ & $(0.000)$ \\
\hline \multirow[t]{2}{*}{ Size } & 0.000 & 0.000 & 0.000 & 0.000 & 0.000 \\
\hline & $(0.628)$ & $(0.316)$ & $(0.279)$ & (0.349) & $(0.312)$ \\
\hline \multirow[t]{2}{*}{$R O A$} & $0.011 * * *$ & $0.011 * * *$ & $0.011 * * *$ & $0.012 * * *$ & $0.010 * * *$ \\
\hline & $(0.002)$ & $(0.001)$ & $(0.002)$ & $(0.002)$ & $(0.003)$ \\
\hline \multirow[t]{2}{*}{ Lev } & 0.001 & 0.001 & 0.001 & 0.002 & 0.001 \\
\hline & $(0.565)$ & $(0.407)$ & $(0.324)$ & $(0.451)$ & $(0.359)$ \\
\hline \multirow[t]{2}{*}{$F C F$} & -0.001 & -0.000 & -0.000 & -0.000 & -0.000 \\
\hline & $(0.555)$ & $(0.643)$ & $(0.727)$ & $(0.623)$ & $(0.685)$ \\
\hline \multirow[t]{2}{*}{ Growth } & 0.000 & 0.000 & 0.000 & 0.000 & 0.000 \\
\hline & $(0.908)$ & $(0.668)$ & $(0.663)$ & $(0.735)$ & $(0.738)$ \\
\hline \multirow[t]{2}{*}{ Topl } & $-0.002 * *$ & -0.002 & -0.002 & -0.002 & -0.002 \\
\hline & $(0.049)$ & $(0.104)$ & $(0.118)$ & $(0.125)$ & (0.159) \\
\hline \multirow[t]{2}{*}{ Herf } & -0.000 & -0.000 & -0.000 & -0.000 & -0.000 \\
\hline & $(0.449)$ & $(0.441)$ & $(0.444)$ & $(0.428)$ & $(0.373)$ \\
\hline
\end{tabular}




\begin{tabular}{llllll}
\hline Dual & -0.000 & -0.000 & -0.000 & -0.000 & -0.000 \\
& $(0.920)$ & $(0.704)$ & $(0.736)$ & $(0.724)$ & $(0.797)$ \\
SOE & 0.000 & 0.000 & 0.001 & 0.000 & 0.001 \\
& $(0.233)$ & $(0.165)$ & $(0.148)$ & $(0.170)$ & $(0.146)$ \\
Salary & $-0.002^{* *}$ & $-0.002^{* *}$ & $-0.002^{* *}$ & $-0.002^{* *}$ & $-0.002^{* *}$ \\
& $(0.011)$ & $(0.013)$ & $(0.013)$ & $(0.015)$ & $(0.016)$ \\
Mratio & -0.001 & -0.003 & -0.005 & -0.002 & -0.003 \\
& $(0.962)$ & $(0.741)$ & $(0.659)$ & $(0.850)$ & $(0.802)$ \\
RPay & -0.000 & -0.000 & -0.000 & -0.000 & -0.000 \\
& $(0.120)$ & $(0.245)$ & $(0.285)$ & $(0.295)$ & $(0.406)$ \\
Compensate & $0.002^{* * *}$ & $0.002^{* * *}$ & $0.002^{* * *}$ & $0.002^{* * *}$ & $0.002^{* * *}$ \\
& $(0.001)$ & $(0.001)$ & $(0.001)$ & $(0.001)$ & $(0.002)$ \\
Age & $-0.000^{* *}$ & $-0.000^{* *}$ & $-0.000^{* *}$ & $-0.000^{* *}$ & $-0.000^{* *}$ \\
& $(0.023)$ & $(0.031)$ & $(0.029)$ & $(0.027)$ & $(0.025)$ \\
Industry & Yes & Yes & Yes & Yes & Yes \\
Year & Yes & Yes & Yes & Yes & Yes \\
\hline$N$ & 2798 & 2798 & 2798 & 2798 & 2798 \\
adj. $R^{2}$ & 0.086 & 0.094 & 0.094 & 0.097 & 0.100 \\
\hline P-valus & & & & & \\
\hline
\end{tabular}

$p$-values in parentheses

${ }^{*} p<0.1,{ }^{* *} p<0.05,{ }^{* * *} p<0.01$, hereinafter the same. 


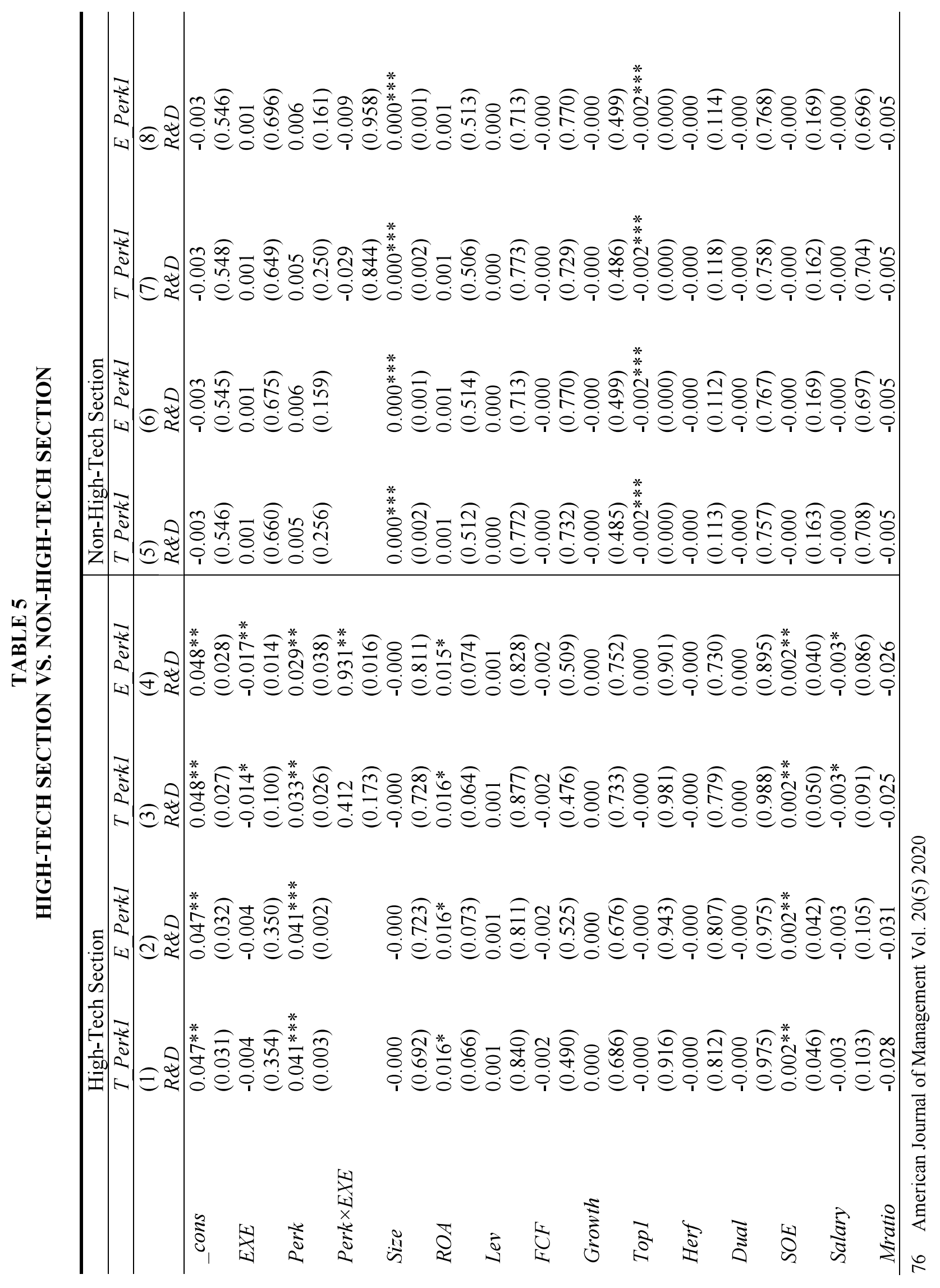




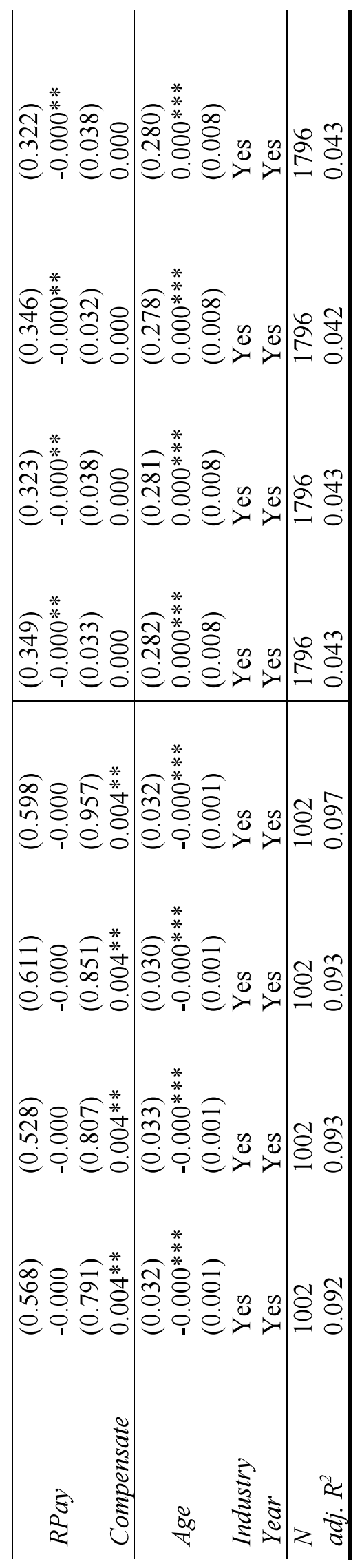




\section{Additional Tests}

The hypothesis of this article believes that work-related perks encourage tolerating (not punishing) the early failure of executives in the process of corporate innovation, thereby increase the executives' risktaking ability, and play a positive role in promoting corporate innovation investment. The characteristics of work-related perks described above are very similar to that of the base salary in currency compensation. Researches such as Chen, Liang, and Jiang (2010) also believe that in the context of China's state-owned enterprise (SOE) executive compensation control system, work-related perks can make up for the lack of monetary compensation incentives. This article speculates that in motivating managers to invest in innovation, work-related perks and managers base salary have mutual substitution effect.

Based on the Pay-Performance Sensitivity (PPS) method (model 4.1) commonly used in salary research such as Jiang (2011), this article calculates the intercept term $\beta_{0}$ as the proxy variable of managers' base salary $F$ Salary, and the slope term $\beta_{1}$ as the proxy variables of the pay-performance sensitivity PerfB_Salary.

$$
\begin{aligned}
\text { Salary }= & \beta_{0}+\beta_{1} \text { Perk }+\beta_{2} \text { Size }+\beta_{3} \text { ROA }+\beta_{4} \text { Lev }+\beta_{5} F C F+\beta_{6} \text { Growth }+\beta_{7} \text { TOPI+ } \beta_{8} \text { Herf } \\
& \beta_{9} \text { Dual }+\beta_{10} \text { SOE }+\beta_{11} \text { Mratio }+\beta_{12} \text { Repay }+\beta_{13} \text { Age }+ \text { Controls }+\sum \text { Industry }+\sum \text { Year }+\varepsilon
\end{aligned}
$$

The test results are shown in Table 6. The coefficient of Perk $\times F$ Salary, which is the interaction item of work-related perks Perk and manager's base salary F Salary, is significantly negative, and the direction is opposite to that of work-related perks Perk and manager's base salary F Salary, indicating that workrelated perks and manager's base salary has the effect of mutual substitution. In addition, the coefficient of performance-based sensitivity PerfB_Salary of manager is significantly negative, indicating that performance-based compensation is not conducive to corporate innovation, which is consistent with Manso's research view (Manso 2011, Ederer and Manso 2014).

TABLE 6

INTERACTION TERM OF WORK-RELATED PERK AND EXECUTIVE FIXED SALARY

\begin{tabular}{|c|c|c|c|c|}
\hline & $T$ Perkl & E Perkl & A Perkl & I Perkl \\
\hline & (1) & (2) & (3) & (4) \\
\hline & $R \& D$ & $R \& D$ & $R \& D$ & $R \& D$ \\
\hline \multirow{2}{*}{ cons } & $0.023 * * *$ & $0.023 * * *$ & $0.026 * * *$ & $0.023 * * *$ \\
\hline & $(0.002)$ & $(0.002)$ & $(0.002)$ & $(0.002)$ \\
\hline \multirow[t]{2}{*}{$E X E$} & 0.003 & 0.003 & 0.003 & 0.003 \\
\hline & $(0.306)$ & $(0.309)$ & $(0.277)$ & $(0.286)$ \\
\hline \multirow[t]{2}{*}{ Perk } & $0.025 * * *$ & $0.024 * * *$ & $0.094 * * *$ & $0.025 * * *$ \\
\hline & $(0.000)$ & $(0.000)$ & $(0.000)$ & $(0.000)$ \\
\hline \multirow[t]{2}{*}{ Perk $\times F$ Salary } & $-0.001 * * *$ & $-0.000 * * *$ & $-0.003 * * *$ & $-0.001 * * *$ \\
\hline & $(0.000)$ & $(0.000)$ & $(0.000)$ & $(0.000)$ \\
\hline \multirow[t]{2}{*}{ F_Salary } & $0.000 * * *$ & -0.000 & $0.000 * * *$ & -0.000 \\
\hline & $(0.006)$ & $(0.786)$ & $(0.001)$ & $(0.366)$ \\
\hline \multirow[t]{2}{*}{ PerfB_Salary } & $-0.000 * * *$ & $-0.000 * *$ & $-0.000 * * *$ & $-0.000 * * *$ \\
\hline & $(0.002)$ & $(0.025)$ & $(0.003)$ & $(0.003)$ \\
\hline \multirow[t]{2}{*}{ Size } & $0.000^{*}$ & $0.000^{*}$ & $0.000^{*}$ & $0.000^{*}$ \\
\hline & $(0.057)$ & $(0.059)$ & $(0.065)$ & $(0.054)$ \\
\hline \multirow[t]{2}{*}{$R O A$} & $0.014 * * *$ & $0.014 * * *$ & $0.015 * * *$ & $0.014 * * *$ \\
\hline & $(0.000)$ & $(0.000)$ & $(0.000)$ & $(0.000)$ \\
\hline
\end{tabular}
AND CORPORATE RESEARCH AND DEVELOPMENT 


\begin{tabular}{|c|c|c|c|c|}
\hline Lev & $\begin{array}{l}0.001 \\
(0.301)\end{array}$ & $\begin{array}{l}0.001 \\
(0.251)\end{array}$ & $\begin{array}{l}0.001 \\
(0.248)\end{array}$ & $\begin{array}{l}0.001 \\
(0.331)\end{array}$ \\
\hline$F C F$ & $\begin{array}{l}0.000 \\
(0.884)\end{array}$ & $\begin{array}{l}0.000 \\
(0.794)\end{array}$ & $\begin{array}{l}0.000 \\
(0.918)\end{array}$ & $\begin{array}{l}0.000 \\
(0.885)\end{array}$ \\
\hline Growth & $\begin{array}{l}0.000 \\
(0.531)\end{array}$ & $\begin{array}{l}0.000 \\
(0.533)\end{array}$ & $\begin{array}{l}0.000 \\
(0.566)\end{array}$ & $\begin{array}{l}0.000 \\
(0.548)\end{array}$ \\
\hline Topl & $\begin{array}{l}-0.002 * * \\
(0.025)\end{array}$ & $\begin{array}{l}-0.002 * * \\
(0.035)\end{array}$ & $\begin{array}{l}-0.002 * * \\
(0.015)\end{array}$ & $\begin{array}{l}-0.002 * * \\
(0.040)\end{array}$ \\
\hline Herf & $\begin{array}{l}-0.001 \\
(0.142)\end{array}$ & $\begin{array}{l}-0.001 \\
(0.163)\end{array}$ & $\begin{array}{l}-0.001 \\
(0.140)\end{array}$ & $\begin{array}{l}-0.001 \\
(0.180)\end{array}$ \\
\hline Dual & $\begin{array}{l}0.000 \\
(0.784)\end{array}$ & $\begin{array}{l}0.000 \\
(0.912)\end{array}$ & $\begin{array}{l}0.000 \\
(0.582)\end{array}$ & $\begin{array}{l}0.000 \\
(0.986)\end{array}$ \\
\hline$S O E$ & $\begin{array}{l}0.000 \\
(0.140)\end{array}$ & $\begin{array}{l}0.000 \\
(0.132)\end{array}$ & $\begin{array}{l}0.001 * \\
(0.097)\end{array}$ & $\begin{array}{l}0.000 \\
(0.199)\end{array}$ \\
\hline Salary & $\begin{array}{l}-0.002 * * * \\
(0.001)\end{array}$ & $\begin{array}{l}-0.002 * * * \\
(0.001)\end{array}$ & $\begin{array}{l}-0.002 * * * \\
(0.001)\end{array}$ & $\begin{array}{l}-0.002 * * * \\
(0.001)\end{array}$ \\
\hline Mratio & $\begin{array}{l}-0.006 \\
(0.503)\end{array}$ & $\begin{array}{l}-0.008 \\
(0.380)\end{array}$ & $\begin{array}{l}-0.007 \\
(0.456)\end{array}$ & $\begin{array}{l}-0.007 \\
(0.455)\end{array}$ \\
\hline RPay & $\begin{array}{l}-0.000^{* *} \\
(0.016)\end{array}$ & $\begin{array}{l}-0.000 * * \\
(0.015)\end{array}$ & $\begin{array}{l}-0.000 * * \\
(0.011)\end{array}$ & $\begin{array}{l}-0.000^{* *} \\
(0.013)\end{array}$ \\
\hline Compensate & $\begin{array}{l}0.003 * * * \\
(0.000)\end{array}$ & $\begin{array}{l}0.003 * * * \\
(0.000)\end{array}$ & $\begin{array}{l}0.003 * * * \\
(0.000)\end{array}$ & $\begin{array}{l}0.003 * * * \\
(0.000)\end{array}$ \\
\hline Age & $\begin{array}{l}-0.000 \\
(0.776)\end{array}$ & $\begin{array}{l}-0.000 \\
(0.698)\end{array}$ & $\begin{array}{l}-0.000 \\
(0.729)\end{array}$ & $\begin{array}{l}-0.000 \\
(0.770)\end{array}$ \\
\hline Industry & Yes & Yes & Yes & Yes \\
\hline Year & Yes & Yes & Yes & Yes \\
\hline $\begin{array}{l}N \\
\text { adj. } R^{2}\end{array}$ & $\begin{array}{l}2628 \\
0.092\end{array}$ & $\begin{array}{l}2628 \\
0.088\end{array}$ & $\begin{array}{l}2628 \\
0.095\end{array}$ & $\begin{array}{l}2628 \\
0.091\end{array}$ \\
\hline
\end{tabular}

\section{Robustness Tests}

Endogenous and Reverse Causality Studies of Dependent Variables and Independent Variables

Grouped by Corporate Governance. In order to eliminate the agency problem hypothesis and the possibility of the endogenous of common influencing factors between the dependent variable and the independent variable, this paper uses corporate governance to group, and retests the hypothesis $\mathrm{H} 1$ and the hypothesis $\mathrm{H} 2$. If the manager uses the enterprise innovation investment process to embezzle because of agency problems, the positive correlation between the dependent variable and the independent variable should be more serious in companies with poor corporate governance. For companies with good corporate governance, due to strict supervision, it is difficult for the manager to embezzle from it through enterprise innovation investment behaviors; therefore, the positive correlation between the dependent variable and the independent variable should be weak or even non-existent. In other words, if the same situation is observed in a company with good corporate governance as a company with poor corporate governance, it means that the positive correlation between the dependent variable and the independent variable is not caused by agency problems or the existence of common influencing factors between the two which indirectly verify the rationality of hypothesis $\mathrm{H} 1$ and hypothesis $\mathrm{H} 2$.

Table 7 is the empirical results grouped by corporate governance. Panel A uses internal corporate governance indicators, and Panel B uses external corporate governance indicators. Internal corporate governance is divided by the median of the shareholding ratio of the largest shareholder in the industry in which the sample company is located, and external corporate governance is divided by the median of the product market competition in the industry in which the sample company is located. The results of Panel A and Panel B show that in the groups with good corporate governance and poor corporate governance, the coefficients of the independent variables Perk of work-related perks and Perk $\times E X E$, which is the interaction 
term of work-related perks and manager equity incentives, are significantly positive (Panel A Except for Perk $\times E X E$ in column 7), it shows that there is no significant difference in the positive correlation between the dependent variable and the independent variable between the two groups, that is, the agency problem hypothesis and the endogeneity of the common influencing factor between the dependent variable and the independent variable are excluded which provides indirect evidence for hypothesis $\mathrm{H} 1$ and hypothesis $\mathrm{H} 2$.

In addition, this article also uses the ratio of independent directors to internal directors and earnings quality as proxy variables for internal corporate governance indicators and external corporate governance indicators, respectively. The results are consistent with our previous conclusion. Due to space constraints, these results are not presented here. 


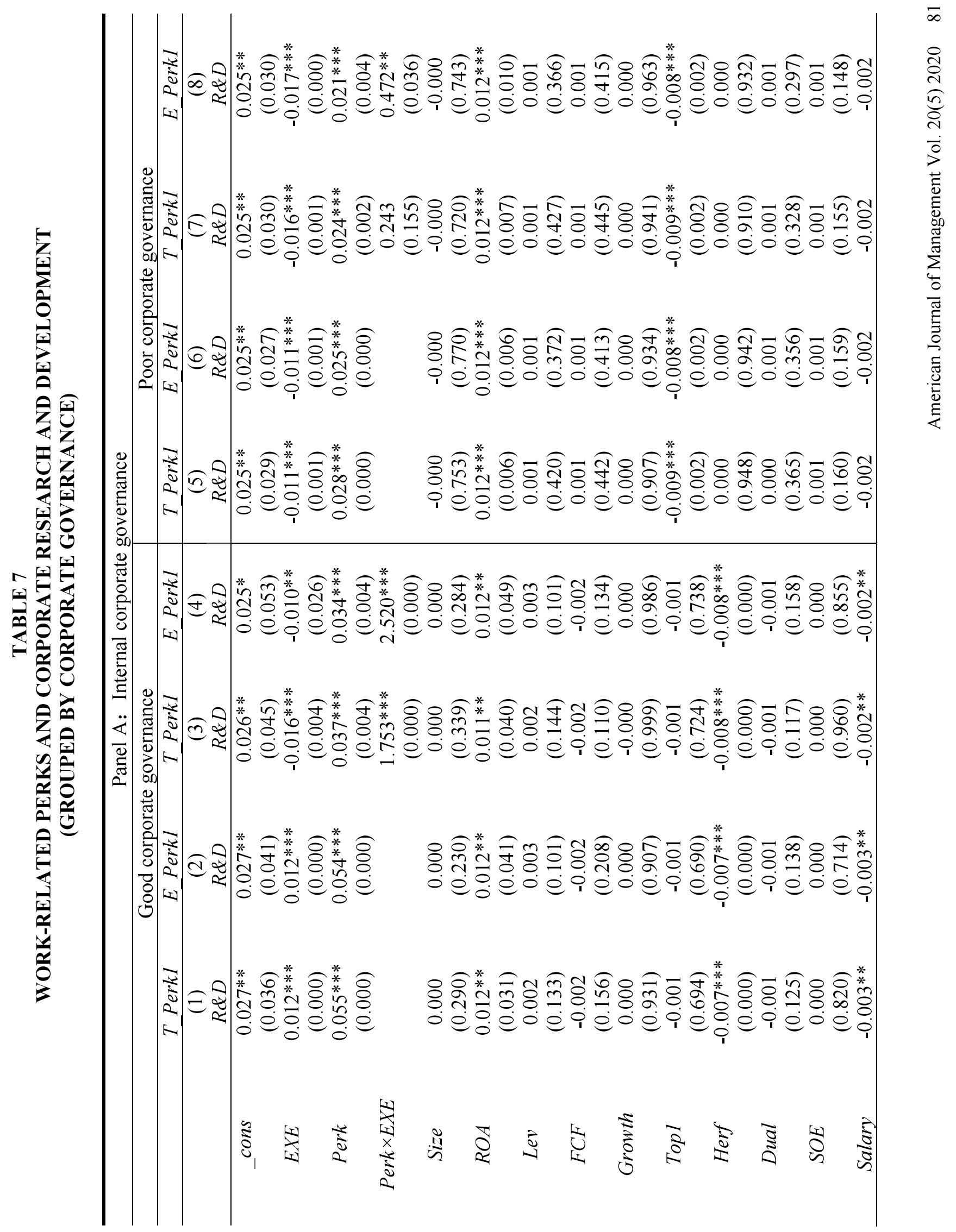




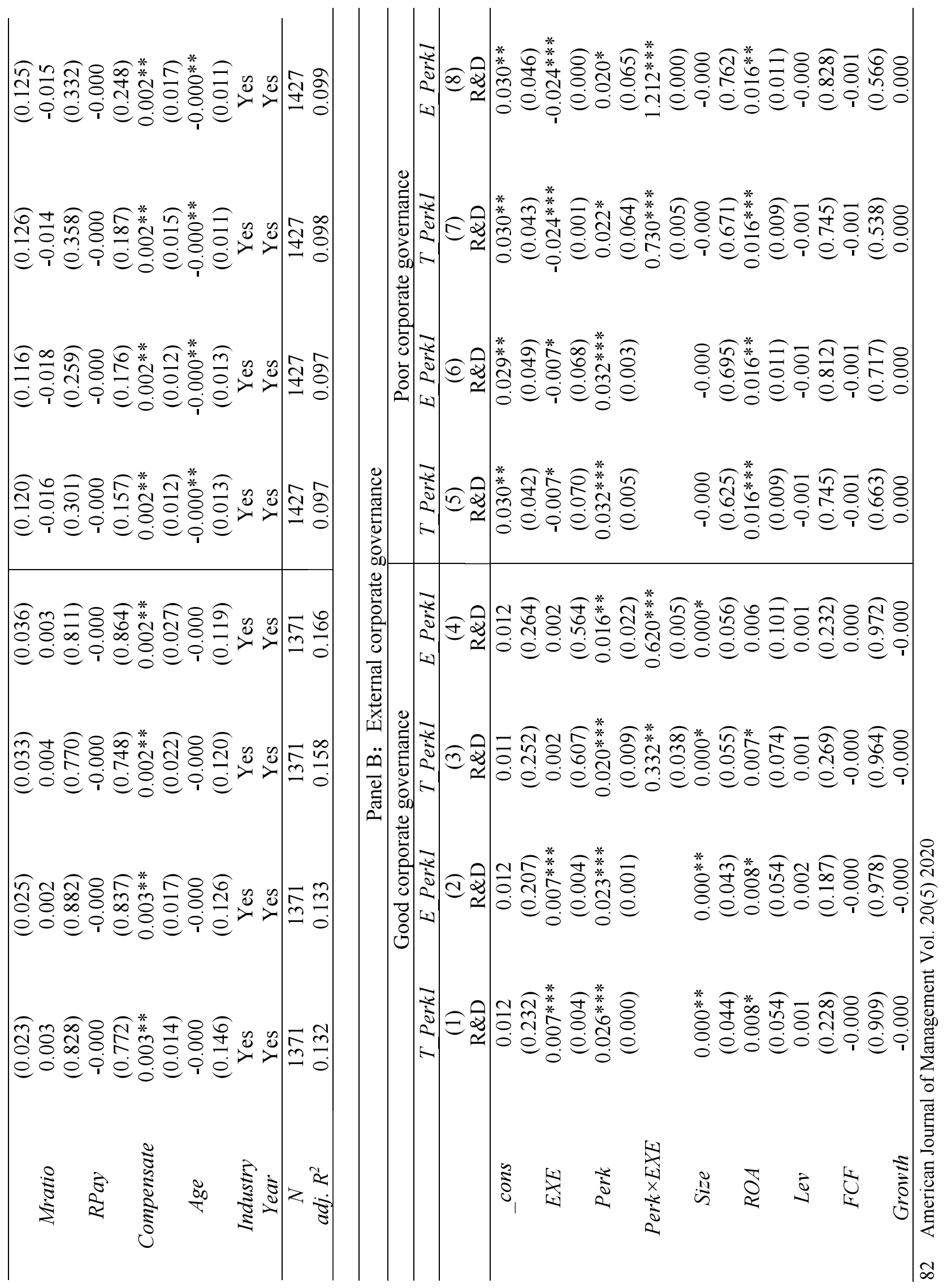




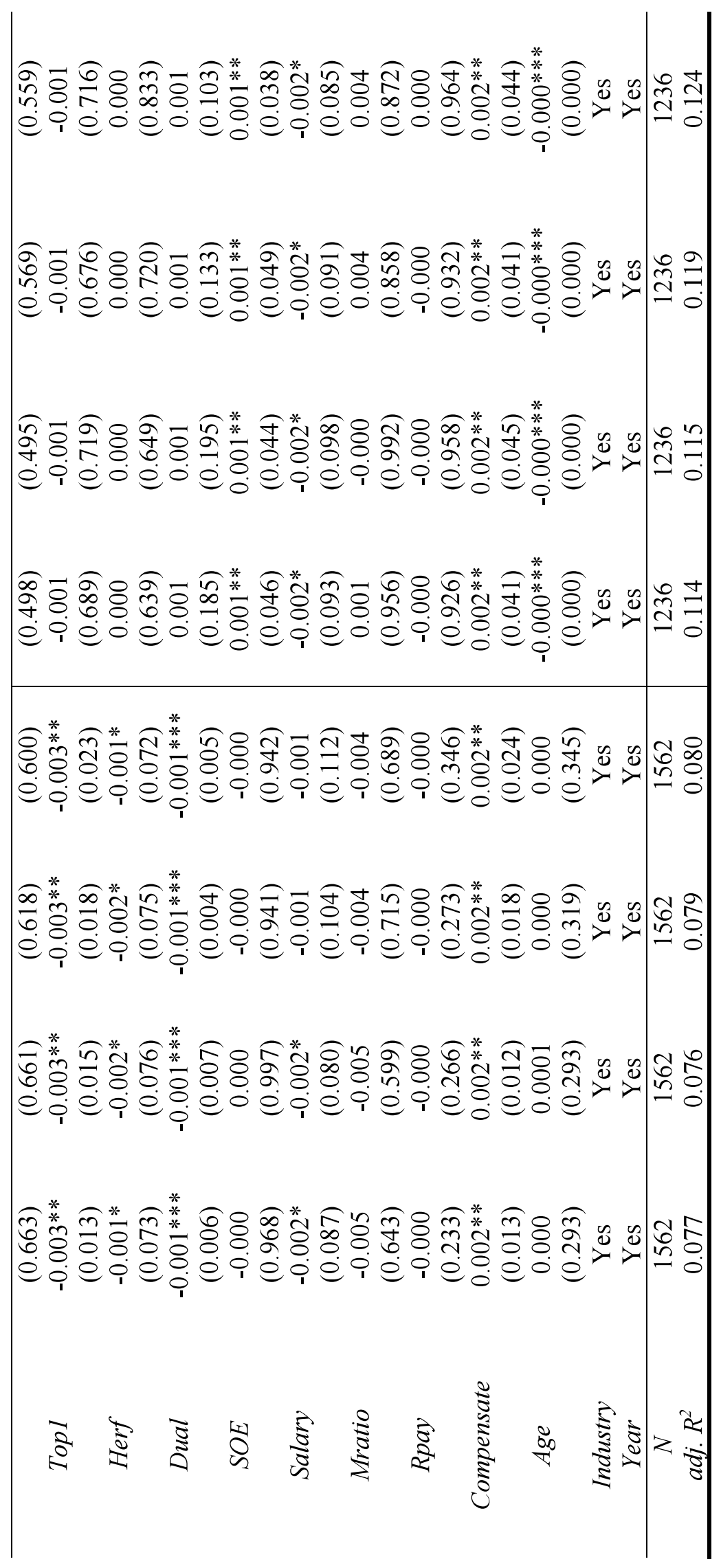


Two-Stage Least Squares (2SLS) Regression Analysis. In order to eliminate the possible endogeneity between manager's work-related perks and corporate $R \& D$ investment, this paper uses 2SLS regression to retest each hypothesis. First the model $(5 \& 6)$ is used to test the hypothesis H1; second on the basis of the model (5), the interaction term Perk $\times E X E$, which is the ratio of work-related perks and manager's shareholding, is added to test the hypothesis $\mathrm{H} 2$; third, companies are grouped by high-tech and non-hightech companies to test hypothesis $\mathrm{H} 3$.

$R \& D=\beta_{0}+\beta_{1}$ Perk + Controls $+\sum$ Ind $+\sum$ Year $+\varepsilon$

Perk $=\beta_{0}+\beta_{1}$ Size $+\beta_{2} R O A+\beta_{3}$ Lev $+\beta_{4}$ TOP $1+\beta_{5}$ Dual $+\beta_{6}$ Comp $++\sum$ Industry+ $\sum$ Year $+\varepsilon$

Table 8 is the regression results of the main part of the hypothesis $\mathrm{H} 1$ and Hypothesis $\mathrm{H} 2$ tested by 2SLS regression. The results show that the coefficient of manager's shareholding ratio EXE is not significant, but in the case of controlling executives' monetary salary and equity incentive $E X E$, The workrelated perks and its interaction with equity incentive $P e r k \times E X E$ are both significantly positively correlated with the company's R\&D expenditure, indicating that work-related perks and the company's R\&D expenditure are strongly correlated. This has proved our hypothesis that work-related perks have incentive effects, and the incentive effects can play a synergistic effect with equity incentives, which verify our hypothesis $\mathrm{H} 1$ and hypothesis $\mathrm{H} 2$. In addition, the results of hypothesis $\mathrm{H} 3$ are consistent with the previous test results, and the results are not presented in this article due to limited space.

TABLE 8

WORK-RELATED PERKS AND CORPORATE R\&D USING 2SLS METHOD

\begin{tabular}{|c|c|c|c|c|}
\hline & T Perkl & E Perkl & $T$ Perkl & E Perkl \\
\hline & (1) & (2) & (3) & (4) \\
\hline & $R \& D$ & $R \& D$ & $R \& D$ & $R \& D$ \\
\hline \multicolumn{5}{|l|}{ Main results } \\
\hline \multirow[t]{2}{*}{ _cons } & 0.006 & 0.005 & 0.007 & 0.006 \\
\hline & $(0.431)$ & $(0.510)$ & $(0.367)$ & $(0.449)$ \\
\hline \multirow[t]{2}{*}{$E X E$} & 0.003 & 0.002 & $-0.008 *$ & $-0.008 * *$ \\
\hline & $(0.255)$ & $(0.317)$ & $(0.074)$ & $(0.024)$ \\
\hline \multirow[t]{2}{*}{ Perk } & $0.133 * * *$ & $0.128 * * *$ & $0.117 * * *$ & $0.112 * * *$ \\
\hline & $(0.000)$ & $(0.000)$ & $(0.000)$ & $(0.000)$ \\
\hline \multirow[t]{2}{*}{ Perk $\times E X E$} & & & $0.523 * * *$ & $0.887 * * *$ \\
\hline & & & $(0.009)$ & $(0.000)$ \\
\hline \multirow[t]{2}{*}{ Size } & $0.001 * * *$ & $0.001 * * *$ & $0.001 * * *$ & $0.001 * * *$ \\
\hline & $(0.002)$ & $(0.000)$ & $(0.005)$ & $(0.001)$ \\
\hline \multirow[t]{2}{*}{$R O A$} & $0.008 * *$ & $0.007 * *$ & $0.008 * *$ & $0.007 * *$ \\
\hline & $(0.018)$ & $(0.032)$ & $(0.024)$ & (0.049) \\
\hline \multirow[t]{2}{*}{ Lev } & -0.000 & 0.001 & -0.000 & 0.001 \\
\hline & $(0.917)$ & $(0.436)$ & $(0.802)$ & $(0.542)$ \\
\hline \multirow[t]{2}{*}{$F C F$} & -0.001 & -0.001 & -0.001 & -0.001 \\
\hline & $(0.366)$ & $(0.433)$ & $(0.336)$ & $(0.380)$ \\
\hline \multirow[t]{2}{*}{ Growth } & 0.000 & 0.000 & 0.000 & 0.000 \\
\hline & $(0.840)$ & $(0.842)$ & $(0.932)$ & $(0.926)$ \\
\hline \multirow[t]{2}{*}{ Topl } & -0.001 & -0.000 & -0.001 & -0.000 \\
\hline & $(0.535)$ & $(0.731)$ & $(0.552)$ & $(0.793)$ \\
\hline Herf & -0.000 & -0.000 & -0.000 & -0.001 \\
\hline
\end{tabular}




\begin{tabular}{lllll}
\hline \multirow{2}{*}{ Dual } & $(0.390)$ & $(0.360)$ & $(0.362)$ & $(0.282)$ \\
& -0.000 & -0.000 & -0.000 & -0.000 \\
SOE & $(0.292)$ & $(0.347)$ & $(0.344)$ & $(0.424)$ \\
Salary & 0.000 & 0.000 & 0.000 & 0.000 \\
& $(0.258)$ & $(0.280)$ & $(0.309)$ & $(0.321)$ \\
Mratio & $-0.001^{* *}$ & $-0.001^{* *}$ & $-0.001^{*}$ & $-0.001^{* *}$ \\
& $(0.050)$ & $(0.041)$ & $(0.053)$ & $(0.044)$ \\
RPay & $-0.023^{* *}$ & $-0.022^{* *}$ & $-0.021^{* *}$ & $-0.019^{* *}$ \\
& $(0.017)$ & $(0.024)$ & $(0.034)$ & $(0.048)$ \\
Compensate & $-0.000^{*}$ & -0.000 & $-0.000^{*}$ & -0.000 \\
& $(0.063)$ & $(0.131)$ & $(0.071)$ & $(0.172)$ \\
Age & $0.002^{* * *}$ & $0.002^{* * *}$ & $0.002^{* * *}$ & $0.002^{* * *}$ \\
& $(0.001)$ & $(0.002)$ & $(0.001)$ & $(0.002)$ \\
Industry & $-0.000^{* * *}$ & $-0.000^{* * *}$ & $-0.000^{* * *}$ & $-0.000^{* * *}$ \\
Year & $(0.008)$ & $(0.005)$ & $(0.009)$ & $(0.006)$ \\
\hline$N$ & Yes & Yes & Yes & Yes \\
\hline
\end{tabular}

Other Measurements of Work-Related Perks

The data on manager's work-related perks in this article is taken from the "Other cash related to operating activities" table in the notes to the financial statements of the annual report. Because the three expenses of office expenses, board fees and meeting fees are extremely controversial. Based on robustness consideration, the three expenses of office expenses, board expenses and meeting expenses are removed from the method of Chen, Liang, and Jiang (2010), only the sum of the remaining five expenses is calculated, and then it is standardized based on company revenue, which is represented by T_Perk2. Correspondingly, the calculation of excess work-related perks also uses $T_{-}$Perk 2 to regress the variables on the right side of the model (2) with the above five expenses standardized by company revenues according to industry and year respectively, and the residual $\varepsilon$ is taken as the manager excess work-related perks, named E_Perk2.

Table 9 is the empirical results of hypothesis $\mathrm{H} 1$ and hypothesis $\mathrm{H} 2$ using T_Perk2 and E_Perk2 as independent variables, and these results are consistent. In addition, the case of using A_Perk1, A_Perk2, I_Perk1, and I_Perk2 as independent variables is also consistent with the case of T_Perk2 and E_Perk2. Due to limited space, these results are not presented in this article.

TABLE 9

REGRESSION RESULTS OF R\&D INVESTMENT ON PERKS OF ROBUSTNESS TESTS

\begin{tabular}{llllll}
\hline & & $T$ Perk2 & $E$ Perk2 & $T$ Perk2 & $E$ Perk2 \\
\hline \multirow{2}{*}{ cons } & $(1)$ & $(2)$ & $(3)$ & $(4)$ & $(5)$ \\
& $R \& D$ & $R \& D$ & $R \& D$ & $R \& D$ & $R \& D$ \\
\multirow{2}{*}{ EXE } & $0.024^{* * *}$ & $0.020^{* *}$ & $0.020^{* *}$ & $0.020^{* *}$ & $0.020^{* *}$ \\
& $(0.006)$ & $(0.020)$ & $(0.021)$ & $(0.020)$ & $(0.022)$ \\
Perk & 0.001 & -0.000 & -0.000 & $-0.009^{* *}$ & $-0.008^{* * *}$ \\
& $(0.529)$ & $(0.996)$ & $(0.974)$ & $(0.019)$ & $(0.008)$ \\
Perk $\times E X E$ & & $0.056^{* * *}$ & $0.055^{* * *}$ & $0.045^{* * *}$ & $0.042^{* * *}$ \\
& & $(0.000)$ & $(0.000)$ & $(0.000)$ & $(0.000)$ \\
Size & & & & $0.594^{* * *}$ & $1.000^{* * *}$ \\
& & & & $(0.003)$ & $(0.000)$ \\
& & & 0.000 & 0.000 & 0.000 \\
\hline
\end{tabular}




\begin{tabular}{|c|c|c|c|c|c|}
\hline & $(0.636)$ & $(0.294)$ & $(0.247)$ & $(0.325)$ & $(0.277)$ \\
\hline \multirow{2}{*}{$R O A$} & $0.011 * * *$ & $0.011 * * *$ & $0.011 * * *$ & $0.012 * * *$ & $0.011 * * *$ \\
\hline & $(0.002)$ & $(0.002)$ & $(0.002)$ & $(0.002)$ & $(0.003)$ \\
\hline \multirow[t]{2}{*}{ Lev } & 0.001 & 0.001 & 0.001 & 0.001 & 0.001 \\
\hline & $(0.561)$ & $(0.383)$ & $(0.302)$ & $(0.412)$ & $(0.325)$ \\
\hline \multirow[t]{2}{*}{$F C F$} & -0.001 & -0.000 & -0.000 & -0.000 & -0.000 \\
\hline & $(0.585)$ & $(0.750)$ & $(0.840)$ & $(0.711)$ & $(0.777)$ \\
\hline \multirow[t]{2}{*}{ Growth } & 0.000 & 0.000 & 0.000 & 0.000 & 0.000 \\
\hline & $(0.908)$ & $(0.619)$ & $(0.612)$ & $(0.689)$ & $(0.691)$ \\
\hline \multirow[t]{2}{*}{ Topl } & $-0.002 * *$ & -0.002 & -0.002 & -0.002 & -0.001 \\
\hline & $(0.048)$ & $(0.123)$ & $(0.138)$ & $(0.143)$ & $(0.183)$ \\
\hline \multirow[t]{2}{*}{ Herf } & -0.000 & -0.000 & -0.000 & -0.000 & -0.000 \\
\hline & $(0.455)$ & $(0.471)$ & $(0.473)$ & $(0.476)$ & $(0.448)$ \\
\hline \multirow[t]{2}{*}{ Dual } & -0.000 & -0.000 & -0.000 & -0.000 & -0.000 \\
\hline & $(0.875)$ & $(0.626)$ & $(0.650)$ & $(0.656)$ & $(0.699)$ \\
\hline \multirow[t]{2}{*}{$S O E$} & 0.000 & 0.000 & 0.000 & 0.000 & 0.000 \\
\hline & $(0.300)$ & $(0.222)$ & $(0.197)$ & $(0.224)$ & $(0.191)$ \\
\hline \multirow[t]{2}{*}{ Salary } & $-0.002 * *$ & $-0.002 * *$ & $-0.002 * *$ & $-0.002 * *$ & $-0.002 * *$ \\
\hline & $(0.015)$ & $(0.018)$ & $(0.017)$ & $(0.019)$ & $(0.019)$ \\
\hline \multirow[t]{2}{*}{ Mratio } & -0.001 & -0.004 & -0.005 & -0.003 & -0.003 \\
\hline & $(0.942)$ & $(0.706)$ & $(0.618)$ & $(0.809)$ & $(0.740)$ \\
\hline \multirow[t]{2}{*}{$R P a y$} & -0.000 & -0.000 & -0.000 & -0.000 & -0.000 \\
\hline & $(0.117)$ & $(0.278)$ & $(0.334)$ & $(0.319)$ & $(0.431)$ \\
\hline \multirow[t]{2}{*}{ Compensate } & $0.002 * * *$ & $0.002 * * *$ & $0.002 * * *$ & $0.002 * * *$ & $0.002 * * *$ \\
\hline & $(0.001)$ & $(0.002)$ & $(0.002)$ & $(0.002)$ & $(0.003)$ \\
\hline \multirow[t]{2}{*}{ Age } & $-0.000 * *$ & $-0.000 * *$ & $-0.000 * *$ & $-0.000 * *$ & $-0.000 * *$ \\
\hline & $(0.022)$ & $(0.028)$ & $(0.026)$ & $(0.024)$ & $(0.023)$ \\
\hline Industry & Yes & Yes & Yes & Yes & Yes \\
\hline Year & Yes & Yes & Yes & Yes & Yes \\
\hline$N$ & 2734 & 2734 & 2734 & 2734 & 2734 \\
\hline $\operatorname{adj} . R^{2}$ & 0.087 & 0.099 & 0.099 & 0.101 & 0.104 \\
\hline
\end{tabular}

\section{CONCLUSION}

As a result of the high risk and high uncertainty of innovative activities, the optimal contract that encourages innovation should not only provide long-term incentives to executives, but also tolerate the early failure of these activities and encourage risk bearing capacity of risk-averse executives. However, the current explicit compensation contracts are simply based on the ex-post performance, and cannot tolerate the early failures of senior executives in innovative practices. Therefore, the current incentive contracts based on long-term performance are not conductive to the corporate innovation activities and performance improvements due to lack of mechanism that encourages executives' risk-taking of early failures of innovation investment.

Different from punitive monetary compensation, work-related perks can compensate to a certain extent for the explicit and hidden costs of the failure of innovation to the executives, which is caused by repeated attempts and errors by the executives without a certain direction. Work-related perks provide guarantees and encourage executives to take the risks of their innovation investment activities, which meets the requirement of "tolerance of early failure" in the optimal contract for encouraging innovation.

Based on the perspective of manager risk-taking and the risk aversion hypothesis, this article takes all A-share listed companies from 2007 to 2012 as a sample and carries out theoretical analysis and empirical testing to assess the role and effect of work-related perks in the contract that encourages executives to invest in innovation activities. The study found: 
(1) Under the control of executives' compensation and equity incentives, work-related perks have incentive effects on enterprise innovation investment, and they work together with equity incentives to generate a synergistic effect in promoting enterprise innovation investment.

(2) The above situation only exists in the subset of high-tech enterprises that are highly dependent on enterprise innovation.

(3) The incentive effect of work-related perks and the fixed currency compensation of manager have a similar mechanism, and the two have a mutual substitution relationship.

(4) The results of this paper are not affected by differences in corporate governance. To a certain extent, it excludes the possibility of manager using the enterprise's innovation activity investment to implement manager embezzlement including work-related perks.

To sum up, in the high-risk and high-uncertain corporate innovation behaviors, work-related perks may improve the executives' risk-taking capacity and enhance their tolerance for early innovation failures, thereby encouraging corporate innovation, and playing a synergistic role with equity incentives.

Research inspiration: when formulating and optimizing contracts that encourage executives to invest in innovation, companies should fully consider the various explicit and implicit costs brought by the high uncertainty and high risk of innovation activities to executives. At the same time, contracts should encourage the tolerance for early failures, comprehensively uses incentive tools such as stock options that reward long-term success and work-related perks that tolerates early failures, so as to provide guarantees for executives' repeated attempts and mistakes in innovative activities without a certain direction, and share their progress. The risks to be assumed in innovation investment activities are to ensure the development of enterprise innovation activities to the greatest extent.

Policy recommendations: when formulating innovation strategies and related industrial policies, the state should fully consider the various costs that the high uncertainty and high risk of innovation activities bring to the enterprise and its manager, and provide corresponding policies and funding levels.

Research Limitation: due to data limitation, companies do not disclose work-related perks; this article

calculates the work-related perks using various indirect methods which may cause certain level of noises been presented in our models.

\section{REFERENCES}

Adam, T.R., Fernando, C.S., \& Golubeva, E. (2015). Managerial overconfidence and corporate risk management. Journal of Banking \& Finance, 60, 195-208.

Amabile, T.M. (1996). Creativity in context: Update to the social psychology of creativity. New York: Routledge.

Ataay, A. (2018). Performance sensitivity of executive pay: the role of ownership structure, board leadership structure and board characteristics. Economic Research Ekonomska Istraživanja, 31(1), 1152-1168.

Atuahene-Gima, K., Slater, S.F., \& Olson, E.M. (2005). The contingent value of responsive and proactive market orientations for new product program performance. Journal of Product Innovation Management, 22(6), 464-482.

Bebchuk, L.A., Fried, J.M., \& Walker, D.I., (2002). Managerial Power and Rent Extraction in the Design of Executive Compensation. The University of Chicago Law Review, 69, 751-846.

Bebchuk, L., \& Grinstein, Y. (2005). The Growth of Executive Pay. Oxford Review of Economic Policy, 2l(2), 283-303.

Bhattacharya, U., Hsu, P., Tian, X., \& Xu, Y. (2017). What Affects Innovation More: Policy or Policy Uncertainty? Journal of Financial and Quantitative Analysis, 52(5), 1869-1901.

Carpenter J.N. (2000). Does option compensation increase managerial risk appetite? The Journal of Finance, 55(5), 2311-2331.

Chang, X., Fu, K., Low, A., \& Zhang, W. (2015). Non-executive employee stock options and corporate innovation. Journal of Financial Economics, 115(1), 168-188. 
Chen, D., Liang, S., \& Jiang, D. (2010). The cost and choice of executive incentive contracts under different marketization processes: Monetary compensation and work-related perks. Accounting Research (China), (11), 56-65.

Chen, H. (2013). CEO Tenure and R\&D Investment: The Moderating Effect of Board Capital. The Journal of Applied Behavioral Science, 49(4), 437-59.

Chen, X., Chen, D., Wan, H., \& Liang, S. (2009). Regional differences, salary control and executive corruption. Management World (China), (11), 130-143.

Chen, Y. S., Lin, M.J.J., \& Chang, C.H. (2009). The positive effects of relationship learning and absorptive capacity on innovation performance and competitive advantage in industrial markets. Industrial Marketing Management, 38(2), 152-158.

Crescenzi, R., \& Gagliardi, L. (2018). The innovative performance of firms in heterogeneous environments: The interplay between external knowledge and internal absorptive capacities. Research Policy, 47(4), 782-795.

Driver, C., \& Guedes, M.J.C. (2017). R\&D and CEO departure date: do financial incentives make CEOs more opportunistic? Industrial and Corporate Change, 26(5), 801-820.

Ederer, F., \& Manso, G. (2014). Is pay for performance detrimental to innovation? Management Science, 59(7), 1496-1513.

Fang, J. (2012). Executive Excess Salary and Corporate Governance Decision. Management World (China), (11), 144-155

Garner, J.L., Nam, J., \& Ottoo, R.E. (2002). Determinants of corporate growth opportunities of emerging firms. Journal of Economics and Business, 54(1), 73-93.

Gormley, T.A., \& Matsa, D.A. (2016). Playing It Safe? Managerial Preferences, Risk, and Agency Conflicts. Journal of Financial Economics, 122(3), 431-455.

Haider, F., Kunst, R., \& Wirl, F. (2020). Total factor productivity, its components and drivers. Empirica.

Jian, J., Li, H., Meng, L., \& Zhao, C. (2020). Do policy burdens induce excessive managerial perks? Evidence from China's stated-owned enterprises. Economic Modelling, 90, 54-65.

Jiang, F., \& Huang, J. (2011). Managerial Incentive, Debt and Firm Value. Economic Research Journal, 46(5), 46-60.

Kiazad, K., Kraimer, M.L., \& Seibert, S.E. (2019). More than Grateful: How Employee Embeddedness Explains the Link between Psychological Contract Fulfillment and Employee Extra-Role Behavior. Human Relations, 72(8), 1315-40.

Li, Z., Dong, Z., \& Lian, Y. (2011). Accrued item earnings management or real activity earnings management. Management World (China), (1), 121-134.

Li, C., \& Song, M. (2010). Innovation Activities in Chinese Manufacturing Firms: The Roles of Firm Ownership and CEO Incentives. Economic Research Journal (China), 45(5), 55-67.

Lin, C., Morck, R.K., Yeung, B.Y., \& Zhao, X. (2016). Anti-Corruption Reforms and Shareholder Valuations: Event Study Evidence from China. NBER Working Paper No. w22001, National Bureau of Economic Research, Inc.

Liu, J. (2007). A Quantitative Analysis of the Impact of R\&D on the Total Factor Productivity of Chinese High-tech Industries. Journal of Industrial Technological Economics (China), 26(5), 51-54.

Liu, Y., \& Liu, W. (2007). The tenure of senior management and R\&D expenditure of listed companies in China. Management World (China), (1), 128-136.

Low, A. (2009). Managerial risk-taking behavior and equity-based compensation. Journal of Financial Economics, 92(3), 470-490.

Lu, R. (2014). Corporate Innovation Investment and the Executive Pay-Performance Sensitivity. Accounting Research (China), (10), 36.

Lu, R., Wei, M., \& Li, W. (2008). Management power, work-related perks and property rights efficiency. Nankai Business Review (China), 11(5), 85-92.

Lu, T., \& Yin, D. (2014). Corporate Governance and Innovation: Differences among Industry Categories. Economic Research Journal, 49(6), 115-128. 
Luo, W., Zhang, Y., \& Zhu, N. (2011). Bank ownership and executive perquisites: New evidence from an emerging market. Journal of Corporate Finance, 17(2), 352-370.

Luo, H., Wan, L., \& Liu, B. (2014). Research on Manipulation of Senior Managers' Salary Contracts in State-owned Enterprises. Journal of Finance and Economics, 40(4), 79-89.

Manso, G. (2011). Motivating innovation. The Journal of Finance, 66(5), 1823-1860.

Marino, A.M., \& Zábojník, J. (2008). Work-Related Perks, Agency Problems, and Optimal Incentive Contracts. The RAND Journal of Economics, 39(2), 565-85.

Quan, X., Wu, S., \& Wen, F. (2010). Managerial Power, Private Income and Compensation Rigging. Economic Research Journal, 45(11), 73-87.

Rajan, R.G., \& Wulf, J. (2006). Are perks purely managerial excess? Journal of Financial Economics, $79(1), 1-33$.

de Rassenfosse, G., Jaffe, A., \& Raiteri, E. (2019). The procurement of innovation by the U.S. government. PLoS One, 14(8), e0218927.

Shen, C., \& Zhang, H. (2012). CEO Risk Incentives and Firm Performance Following R\&D Increases. Journal of Banking \& Finance, 37(4).

Tchistyi, A., Yermack, D., \& Yun, H. (2011). Negative Hedging: Performance-Sensitive Debt and CEOs' Equity Incentives. Journal of Financial and Quantitative Analysis, 46(3), 657-686.

Thornton, J., Jr., Knopf, J., \& Nam, J. (2002). The Volatility and Price Sensitivities of Managerial Stock Option Portfolios and Corporate Hedging. Journal of Finance, 57(2), 801-813.

Wen, J., \& Feng, G. (2009). Heterogeneous Institutional Investor, Nature of Firm and Independent Innovation. Economic Research Journal, 3.

Wiseman, R.M., \& Gomez-Mejia, L.R. (1998). A Behavioral Agency Model of Managerial Risk Taking. The Academy of Management Review, 23(1), 133-53. 